\title{
Effect of swimming with the use of aqua fitness elements and interval hypoxic training on the physical fitness of boys aged 11-12 years
}

\author{
Furman Yu. M. ${ }^{1 \mathrm{ABCDE}}$, Holovkina V.V. ${ }^{1 \mathrm{ABCDE}}$, Salnykova S.V. ${ }^{2 \mathrm{ABDE}}$, Sulyma A.S. ${ }^{1 \mathrm{ABDE}}$, Brezdeniuk O.Yu. ${ }^{3 \mathrm{ABDE}}$, \\ Korolchuk A.P. ${ }^{1 \mathrm{ABDE}}$, Nesterova S.Yu. ${ }^{1 \mathrm{ABDE}}$ \\ ${ }^{1}$ Department of Biomedical Foundations of Physical Education and Physical Rehabilitation, Vinnytsia Mykhailo \\ Kotsiubynskyi State Pedagogical University, Ukraine; \\ ${ }^{2}$ Department of Philosophy and Economic, Vinnytsia institute of trade and economics of Kyiv national university of \\ trade and economics, Ukraine; \\ ${ }^{3}$ Department of Physical Education, Vinnytsia Mykhailo Kotsiubynskyi State Pedagogical University, Ukraine
}

Authors' Contribution: A - Study design; B - Data collection; C - Statistical analysis; D - Manuscript Preparation; E - Funds Collection.

\begin{tabular}{|c|c|}
\hline \multicolumn{2}{|l|}{ Abstract } \\
\hline Purpose: & $\begin{array}{l}\text { to establish the integrated effect of training sessions using elements of aqua fitness and interval hypoxic } \\
\text { training on the special physical fitness of swimmers. }\end{array}$ \\
\hline Material: & $\begin{array}{l}\text { young swimmers participated in the study }(n=64 \text {, age } 11-12, \text { sporting experience }-2-3 \text { years). The research } \\
\text { was carried out in stages: before the experiment began, and then in } 8,16 \text { and } 24 \text { weeks later. Frequency of } \\
\text { classes in all groups was } 6 \text { times a week. }\end{array}$ \\
\hline Results: & $\begin{array}{l}\text { the ability to work in anaerobic alactatic, lactate and aerobic energy supply zones was studied. It was } \\
\text { established that such training sessions help to improve the performance and capacity of the anaerobic } \\
\text { alactatious system. The feasibility of such combination is proved by the growth of performance indicators in } \\
\text { areas of aerobic, anaerobic alactatic and lactate energy supply. }\end{array}$ \\
\hline Conclusions: & $\begin{array}{l}\text { The feasibility of such training sessions is explained by: minimizing the negative impact on the children's } \\
\text { body of exercises on the development of force in conditions of the aquatic environment; improving the } \\
\text { functional capabilities of the body. }\end{array}$ \\
\hline & hilitur a \\
\hline
\end{tabular}

\section{Introduction}

The results of the competitions (Olympics, World Championships, etc.) indicate the dynamics of the growth rates of performance from different sports. Such a phenomenon is conditioned by an increase in the efficiency of training sessions by introducing new technologies into the multi-year training of athletes [1-3].

An essential role in the training of young swimmers is to improve the strength of qualities [4]. Power training, [5] when working with swimmers, is carried out in the dryswimming area. However, performing power exercises under such conditions can negatively affect the functional [6] preparedness of young swimmers. Therefore, we propose a part time program (force training in the dryswimming area) to replace aqua fitness [7].

There is evidence that physical exercising in water has a positive effect on various functional systems of the body [8]. Such an effect of physical exercises in water is due to the following: phenomenon of gravity unloading of the body [9]; positive influence on the function of the cardiovascular system [10], respiratory systems [11] and vestibular apparatus [12].

Recently, in the physical education of people of different ages, auxiliary agents are used which increase the effectiveness of physical exercises [13-15]. It has been proved that the use of endogenous-hypoxic breathing techniques in cycling [16] and swimmers [17] positively (c) Furman Yu. M., Holovkina V.V., Salnykova S.V., Sulyma A.S. , Brezdeniuk O.Yu. , Korolchuk A.P. , Nesterova S.Yu., 2018 doi:10.15561/18189172.2018.0403 influences the dynamics of physical fitness. Other studies are evidence of the effectiveness of endogenous-hypoxic respiration when working with skilled hockey players on grass [18] and on ice [19]. Interval hypoxic training is used in practice of other sports: rugby [20, 21]; cycling [22]

Other authors [8, 11] proved the effectiveness of complex application of aqua fitness and endogenoushypoxic respiration techniques when working with women of mature age. This is confirmed by the improvement of their physical condition [7]. Different breathing techniques are used in the preparation of swimmers [2325]. The authors state:

- The effects of intermittent hypoxia training on blood, serum and other indicators and the effect of swimming training were analyzed. The practice has proved that the intermittent hypoxia training method was an economical and practical method, which can replace the traditional altitude training and improve the oxygen transport ability of the swimming athletes effectively [9];

- This study demonstrated that VHL (VHL group - low lung volume) training, when performed at supramaximal intensity, represents an effective method for improving swimming performance, partly through an increase in the anaerobic glycolysis activity [25];

- $\mathrm{RSH}-\mathrm{VHL}$ (RSH - repeated-sprint training in hypoxia) improved RSA (RSA - repeated-sprint 
ability) in swimming, probably through enhanced anaerobic glycolysis. This innovative method allows inducing benefits normally associated with hypoxia during swim training in normoxia [24].

In the program for the training of young swimmers, we propose to integrate the elements of aqua fitness and the method of interval hypoxic training (IHT) using the apparatus "Endogenic-01" [26]. There are no scientific data on the possibility of using ICT in combination with aqua fitness in the training process of swimmers of 11-12 years old.

Hypothesis. We anticipate that the integrated application of the endogenous hypoxic respiration method and the elements of aqua fitness in the training process of young swimmers will enhance their functional, general and special physical fitness.

The purpose of the study: to establish the complex impact of training sessions on elements of aqua fitness and the methods of interval hypoxic training on the special physical fitness of swimmers 11-12 years old.

\section{Materials and methods.}

Participants. In the experiment participated students of children's and youth sports schools - boys aged 11-12 years ( $n=64$, sports experience - 2-3 years). Of these, there are three groups: control $(\mathrm{CG}, \mathrm{n}=21)$, the first basic (MG1, $\mathrm{n}=22$ ) and the second main (MG2, $\mathrm{n}=21$ ).

Organization of research. It was used the following swimming tests: "swimming with free style at a distance of 25 meters", "freestyle swimming at distances of $4 \times 50 \mathrm{~m}$ with a rest interval of 15 seconds"; "swimming with free style at a distance of $800 \mathrm{~m}$ ”. It was also applied test to record the number of twists of 25 meters in the maximum possible speed (anaerobic mode of power supply). The number of repetitions was limited to an excess of heart rate of 170 bits per minute ${ }^{-1}$ [17].

The research was carried out in stages: before the experiment begin, and then in 8, 16 and 24 weeks later.

Frequency of classes in all groups was 6 times a week. The content of the classes in the main groups was different from the control. Athletes of the first main group on each training session at the beginning of the preparatory part used interval hypoxic training (IHT) under the program of special "route maps" [26]. For this purpose, the device "Endogenic-01" was used.

Strength training for athletes of the second main group was carried out in water using elements of the aqua fitness power direction [7]. In the process of training used such aids as water belts, gloves, small and large dumbbells, nulls, boots, rubber shock absorbers, swimming boards [27].

Statistical analysis. Summing up are numerical indices that reflect the position of the center of empirical distributions and their scattering: arithmetic mean (x); mean arithmetic mean error (m); mean square (standard) deviation (S); dispersion (S2); coefficient of variation (V).

The values of the sample from the general population were subject to the law of normal distribution, which was verified using Pearson's criterion. Student's t-criterion was used [28]. The difference was considered probable with a difference of $5 \%(\mathrm{p}<0.05)$.

\section{Results.}

Studies of special physical fitness of swimmers from the CG group showed that training sessions during 24 weeks did not cause any significant changes in any of the studied parameters.

Training sessions for swimming for 8 weeks in the group MG1 and the group MG2 did not cause any of the indicators of special physical fitness.

Six weeks after the beginning of classes in boys of the group MG1, an improvement $(5.85 \%$, p <0.05) of the results of the first segment gliding recorded in the " $4 \times 50 \mathrm{~m}$ freestyle skating test with a rest interval of 15 sec" was registered (Table 1)

In the group MG2 (after 16 weeks), the " $800 \mathrm{~m}$ freestyle" and "free $25 \mathrm{~m}$ style flying with the highest possible speed" test dropped by $2.81 \%$ and $4.13 \%$. In this group, the time to overcome the first and second segments in the test " $4 \times 50 \mathrm{~m}$ free-range driving with a rest interval of 15 seconds" decreased by $5.11 \%$ and $5.00 \%$, respectively. Also, the number of sailings of 25-meter intervals with maximum intensity (heart rate $150-170$ bits per minute ${ }^{-1}$ ) has increased (by 21.15\%) (Table 1).

Boys of groups MG1 and MG2 (after 24 weeks) improved their results of performing tests that characterize the capacity in aerobic energy supply zone (by 3.42\% and $5.66 \%$ ) and efficiency in anaerobic alactated energy supply zone (by $6.22 \%$ and $9.26 \%$ ). The capacity of an anaerobic alactatic system grew by $25.93 \%$ and $38.46 \%$ respectively.

Athletes of the group MG1 (after 24 weeks) decreased the time to overcome the first segment in the test " $4 \times 50 \mathrm{~m}$ freestyle diving with a rest interval of 15 s” by $6.22 \%$. In the second segment decreased by $5.86 \%$. In the group MG2, the results of the first and second segments in this test improved by $9.48 \%$ and $6.23 \%$ respectively.

\section{Discussion.}

The results of control competitive testing of swimming are confirmed by the results of research by scientists $[9,17]$ on the limitation of the ability of swimmers of adolescence to perform work under conditions of anaerobic metabolism.

The information of scientists [9, 27] on the effectiveness of using interval hypoxic training in the system training of athletes has been confirmed and supplemented. Other authors $[9,17]$ used the technique of interval hypoxic training in swimmers. After 16 weeks of training sessions swimmers had a probable increase in work capacity in the area of aerobic and anaerobic lactate energy supply. The results of their own research have shown that the use of IHT in the training process of swimmers aged 11-12 years contributes to improving efficiency in areas of aerobic, anaerobic alactatious and lactate energy supply. The expediency of using our proposed program of training sessions with swimmers of 11-12 years old is also indicated by an increase in the capacity of anaerobic 
Table 1. Indicators of special physical fitness of $11-12$ years old swimmers at different stages of the study (CG, $n=21$, MG1, $n=22, M G 2, n=21$ )

\begin{tabular}{|c|c|c|c|c|c|c|}
\hline \multirow{2}{*}{\multicolumn{2}{|c|}{ Indexes }} & \multirow{2}{*}{$\begin{array}{l}\text { Groups } \\
\text { Before } \\
\text { exercises start }\end{array}$} & \multicolumn{4}{|c|}{ Mean value, $x \pm S$} \\
\hline & & & After 8 weeks & $\begin{array}{l}\text { after } 16 \\
\text { weeks }\end{array}$ & $\begin{array}{l}\text { after } 24 \\
\text { weeks }\end{array}$ & \\
\hline \multirow{2}{*}{\multicolumn{2}{|c|}{$\begin{array}{l}\text { Freestyle swimming } 800 \mathrm{~m} \text {, sec } \\
\text { MG1 }\end{array}$}} & CG & $798,24 \pm 7,28$ & $793,38 \pm 8,28$ & $790,19 \pm 8,46$ & $776,57 \pm 7,99$ \\
\hline & & $797,82 \pm 7,25$ & $790,59 \pm 6,68$ & $778,27 \pm 6,68$ & $770,55 \pm 6,34^{*}$ & \\
\hline \multicolumn{2}{|l|}{ MG 2} & $799,71 \pm 6,86$ & $790,05 \pm 5,50$ & $777,24 \pm 5,15^{*}$ & $754,43 \pm 4,32 *$ & \\
\hline \multirow{8}{*}{$\begin{array}{l}\text { Freestyle } \\
\text { swimming } \\
4 \times 50 \mathrm{~m} \\
\text { with a rest } \\
\text { interval } 15 \\
\text { sec: }\end{array}$} & \multirow{3}{*}{ 1st length, sec } & CG & $35,06 \pm 0,51$ & $35,01 \pm 0,41$ & $34,86 \pm 0,41$ & $33,70 \pm 0,44$ \\
\hline & & MG 1 & $35,09 \pm 0,80$ & $35,06 \pm 0,80$ & $33,04 \pm 0,59 *$ & $32,91 \pm 0,60 *$ \\
\hline & & MG 2 & $35,30 \pm 0,67$ & $35,17 \pm 0,67$ & $33,50 \pm 0,55^{*}$ & $31,96 \pm 0,50 *$ \\
\hline & \multirow{2}{*}{$2 d$ length, sec } & CG & $37,86 \pm 0,51$ & $37,81 \pm 0,51$ & $37,78 \pm 0,51$ & $37,38 \pm 0,52$ \\
\hline & & MG 1 & $37,96 \pm 0,83$ & $37,89 \pm 0,83$ & $36,69 \pm 0,70$ & $35,73 \pm 0,67 *$ \\
\hline & \multirow{3}{*}{$3 d$ length, sec } & MG 2 & $38,01 \pm 0,68$ & $37,92 \pm 0,67$ & $36,11 \pm 0,59 *$ & $35,64 \pm 0,61^{*}$ \\
\hline & & CG & $40,48 \pm 0,61$ & $40,37 \pm 0,61$ & $40,27 \pm 0,62$ & $39,74 \pm 0,63$ \\
\hline & & MG 1 & $40,84 \pm 0,85$ & $40,75 \pm 0,85$ & $40,58 \pm 0,85$ & $40,04 \pm 0,83$ \\
\hline \multirow{4}{*}{\multicolumn{2}{|c|}{ 4th length, sec }} & MG 2 & $40,71 \pm 0,71$ & $40,57 \pm 0,69$ & $40,36 \pm 0,69$ & $39,27 \pm 0,59$ \\
\hline & & CG & $43,35 \pm 0,78$ & $43,29 \pm 0,78$ & $43,21 \pm 0,77$ & $42,69 \pm 0,77$ \\
\hline & & MG 1 & $43,61 \pm 0,85$ & $43,52 \pm 0,85$ & $43,29 \pm 0,86$ & $42,15 \pm 0,76$ \\
\hline & & MG 2 & $43,42 \pm 0,74$ & $43,29 \pm 0,75$ & $43,08 \pm 0,76$ & $41,64 \pm 0,64$ \\
\hline \multirow{3}{*}{\multicolumn{2}{|c|}{$\begin{array}{l}\text { Freestyle swimming on } 25 \mathrm{~m} \text {, } \\
\text { sec } \\
\text { MG } 1 \\
\text { MG } 2\end{array}$}} & CG & $15,80 \pm 0,23$ & $15,75 \pm 0,24$ & $15,64 \pm 0,24$ & $15,50 \pm 0,24$ \\
\hline & & $15,79 \pm 0,35$ & $15,74 \pm 0,34$ & $15,15 \pm 0,34$ & $14,48 \pm 0,31^{*}$ & \\
\hline & & $15,85 \pm 0,26$ & $15,63 \pm 0,24$ & $15,20 \pm 0,15^{*}$ & $14,39 \pm 0,16^{*}$ & \\
\hline \multirow{2}{*}{\multicolumn{2}{|c|}{$\begin{array}{l}\text { Swim distances } 25 \text { m with HR } \\
150-170 \text { bits per minute }{ }^{-1} \text {, } \\
\text { number of length }\end{array}$}} & CG & $2,48 \pm 0,18$ & $2,71 \pm 0,12$ & $2,76 \pm 0,12$ & \multirow[t]{3}{*}{$2,86 \pm 0,12$} \\
\hline & & $2,45 \pm 0,17$ & $2,73 \pm 0,11$ & $2,86 \pm 0,11$ & $3,09 \pm 0,11^{*}$ & \\
\hline \multicolumn{2}{|c|}{$\begin{array}{l}\text { MG } 1 \\
\text { MG } 2\end{array}$} & $2,48 \pm 0,18$ & $2,86 \pm 0,12$ & $3,00 \pm 0,12 *$ & $3,43 \pm 0,12 *$ & \\
\hline
\end{tabular}

Note: $H R$ is the heart rate.

alactated energy supply system for young swimmers.

For the first time, elements of aqua fitness and interval hypoxic training were used in the training process of young swimmers. The expediency of such innovation, we explain: minimizing the negative impact on children's body of exercises on the development of force in conditions of the aquatic environment; improving the functional capabilities of the body. The benefits of such combination are evidenced by the results of studies of special physical fitness after the completion of the molding experiment. In athletes of the MG2 group, after 24 weeks, the efficiency in the aerobic energy supply zone was significantly higher compared to the results of the groups of CG and MG1 (2.85\% and 2.09\%). The capacity of the anaerobic alactatious system of young swimmers by $20.00 \%$ and $10.92 \%$ exceeded the indicators of the groups of CG and MG1.

The time to overcome the distance of $25 \mathrm{~m}$ in free style with the highest possible speed in the group MG2 was
$7.21 \%$ better than in the CG group. The time of sailing of the first and second segments at a distance of $4 \times 50 \mathrm{~m}$ free style with an interval of 15 seconds also improved by $5.18 \%$ and $4.65 \%$ respectively.

The results of the implementation of control tests by the swimmers of the group MG2 supplemented the scientific information of other authors [8, 10, 27] on the effectiveness of the use of aqua fitness in training sessions. The correctness of our approaches to improving the physical condition of children is confirmed by other studies [29, 30].

\section{Conclusions}

The results of the research showed that training sessions with swimming with the use of elements of aqua fitness and interval hypoxic training contribute to improving the efficiency of swimmers of 11-12 years old in the zone of aerobic, anaerobic alactatious and anaerobic lactate energy supply. 


\section{Financing}

The research was carried out in accordance with the plan of research work of the Department of Medical and Biological Foundations of Physical Education and Rehabilitation of the Vinnitsa State Pedagogical University named after Mikhail Kotsyubinsky for 2017-
2018 "Integrated application of physical education and methods of endogenous-hypoxic respiration” to improve the physical condition of persons in the Podillya region»

\section{Conflict of interest.}

The authors state that there is no conflict of interest.

\section{References:}

1. Holovkina V, Furman Yu. Comparative characteristic of general physical preparedness of swimmers of 11-12 years old depending on sex and possibilities of its improvement by means of aquaphthesis and interval hypoxic training. Fizichna kul'tura, sport ta zdorov'ia nacii, 2017; 3(22): 258263.

2. Cieszczyk P, Willard K, Gronek P, Zmijewski P, Trybek $\mathrm{G}$, Gronek J, et al. Are genes encoding proteoglycans really associated with the risk of anterior cruciate ligament rupture? Biology of Sport, 2017;34(2):97-103. doi:10.5114/ biolsport.2017.64582

3. Doroshenko EY, Svatyev AV, Iermakov SS, Jagiełło W. The use of cardio training facilities in training 7-9 year old judo athletes. Arch Budo Sci Martial Art Extreme Sport, 2017;13:165-172.

4. Holovkina VV. Prospects of interval hypoxic training and elements of aqua fitness application in the process of physical training of swimmers 11-12 years old. Fizichna kul'tura, sport ta zdorov'ia nacii, 2016; 20: 454-459. (in Ukrainian)

5. Prystupa E, Briskin Y, Pityn M, Blavt O. The role of olympic education in solving problems of modern generation Physical activity, sport and health. 2012; 3(9): 3-10.

6. Davydov V. Mankevich A, Morozova O. Selection of 7-10 years old children of different types of constitution in sport swimming, taking into account their psychological and physiological features. Fizichne vikhovannia, sport $i$ kul'tura zdorov'ia u suchasnomu suspil'stvi, 2017; 2(38): 68 - 74. (in Ukrainian)

7. Salnykova S, Hruzevych I, Bohuslavska V, Nakonechnyi I, Kyselytsia O, Pityn M. Combined application of aquafitness and the endogenous-hypoxic breathing technique for the improvement of physical condition of 30-49-year-old women. Journal of Physical Education and Sport. 2017; 17(4): 2544-2552. doi:10.7752/jpes.2017.04288

8. Rodriguez-Zamora L, Engan HK, Lodin-Sundstrom A, Schagatay F, Iglesias X, Rodriguez FA, et al. Blood lactate accumulation during competitive freediving and synchronized swimming. Undersea and Hyperbaric Medicine. 2018;45(1):55-63.

9. Hruzevych I, Bohuslavska V, Kropta R, Galan Ya, Nakonechnyi I, Pityn $M$. The effectiveness of the endogenous-hypoxic breathing in the physical training of skilled swimmers. Journal of Physical Education and Sport (JPES), 2017; 17 (3): 1009-1016. doi:10.7752/jpes.2017. s3155

10.Holovkina V, Salnykova S. Dynamics of indicators of aerobic and anaerobic productivity of an organism of 11-12 years old swimmers under the influence of training sessions with the use of aqua fitness elements and interval hypoxic training. Visnik Prikarpats'kogo universitetu, 2017; 25-26: 66-72. (in Ukrainian)

11.Salnykova SV. Comparative characteristics of the physical condition of women 30-49 years old of physical fitness indicators, depending on the fat content of the body mass. Fizichne vikhovannia, sport i kul'tura zdorov'ia u suchasnomu suspil'stvi, 2017; 1:77 - 82. (in Ukrainian)

12.Kenney LW, Wilmore JH, Costill DL. Physiology of Sport and Exercise. Champaign: Human Kinetics; 2012.

13.Antonio J, Stout JR. Supplements for endurance athletes. Champain, Illinois: Human Kinetics; 2003.

14.Kolchinskaya AZ. Interval Hypoxic Training in Sports. Hypoxia Med. J.,1993; 2: 28 - 33.

15.Weber-Rajek M, Radziminska A, Slominski K, LulinskaKuklik E. Evaluation of the Effectivenness of Sonotherapy in the Treatment of Chronic Pain Syndromes of the Lumbosacral Spine - Pilot Study. Acta Balneologica. 2017;59(2):104-110. 16.Czuba M, Fidos-Czuba O, Ploszczyca K, Zajac A, Langfort J. Comparison of the effect of intermittent hypoxic training vs. the live high, train low strategy on aerobic capacity and sports performance in cyclists in normoxia. Biology of Sport. 2018;35(1):39-48. doi:10.5114/biolsport.2018.70750

17.Han JJ, Huang K, Shi SW, Lu ZD. Application of Physiological Training Mechanism of Intermittent Hypoxia Training in Swimming Competition. Journal of Advanced Oxidation Technologies. 2018;21(2). doi:10.26802/jaots.2018.12399

18.Furman Yu, Sulyma A. Influence of endogenous-hypoxic respiration on restoration of the function of the cardiovascular system of qualified hockey players on the grass after dosed physical activity. Molodizhnij naukovij visnik, 2015; 18: 240 - 245. (in Ukrainian)

19.Brocherie F, Millet GP, Girard O. Psychophysiological Responses to Repeated-Sprint Training in Normobaric Hypoxia and Normoxia. International Journal of Sports Physiology and Performance. 2017;12(1):115-123. doi:10.1123/ijspp.2016-0052

20.Hamlin MJ, Olsen PD, Marshall HC, Lizamore CA, Elliot CA. Hypoxic Repeat Sprint Training Improves Rugby Player's Repeated Sprint but Not Endurance Performance. Frontiers in Physiology. 2017;8. doi:10.3389/fphys.2017.00024

21.Fornasier-Santos C, Millet GP, Woorons X. Repeated-sprint training in hypoxia induced by voluntary hypoventilation improves running repeated-sprint ability in rugby players. European Journal of Sport Science. 2018;18(4):504-512. doi $: 10.1080 / 17461391.2018 .1431312$

22.Inness MWH, Billaut F, Aughey RJ. Team-Sport Athletes' Improvement of Performance on the Yo-Yo Intermittent Recovery Test Level 2, but Not of Time-Trial Performance, With Intermittent Hypoxic Training. International Journal of Sports Physiology and Performance. 2016;11(1):15-21. doi:10.1123/ijspp.2014-0246

23.Toubekis AG, Beidaris N, Botonis PG, Koskolou M. Severe hypoxemia induced by prolonged expiration and reduced frequency breathing during submaximal swimming. Journal of Sports Sciences. 2017;35(11):1025-1033. doi:10.1080/026 40414.2016.1209304

24.Trincat L, Woorons X, Millet GP. Repeated-Sprint Training in Hypoxia Induced by Voluntary Hypoventilation in Swimming. International Journal of Sports Physiology and Performance. 2017;12(3):329-335. doi:10.1123/ ijspp.2015-0674

25.Woorons X, Mucci P, Richalet JP, Pichon A. Hypoventilation 
Training at Supramaximal Intensity Improves Swimming Performance. Medicine and Science in Sports and Exercise. 2016;48(6):1119-1128. doi:10.1249/mss.0000000000000863 26.Khodorovs'kij GI, Koliasko IV, Furkal IeS, Koliasko NI, Kuznecova OV, Iasins'ka OV. Endogenous-hypoxic respiration. Chernivtsi: Theory and practice; 2006. (in Ukrainian)

27.Zhuk A, Habinets T. Efficiency of Aqua Fitness in Physical Education of Junior Schoolchildren. Molodizhnij naukovij visnik, 2012; 7: 60-63. (in Ukrainian)

28.Kulikov MA, Shastun SA. Agadzhanian MA, Korobkov A.V.
Statistical methods of processing the results of physiological experiments. Moscow: High school; 1983. (in Russian)

29.Arazi H, Jalali-Fard A, Abdinejad H. A comparison of two aerobic training methods (running vs rope jumping) on healthrelated physical fitness in 10 to 12 years old boys. Physical Activity Review. 2016;4:9-17. doi:10.16926/par.2016.04.02

30.Maciulevičienè E. 10-11 classes students and physical education teachers subjective opinions about their physical education lessons modernity. Human. Sport. Medicine, 2017; 16(2), 67-70. doi:10.14529/hsm160207

Information about the authors:

Furman Yu. M.; http://orcid.org/0000-0002-5206-7712; furman-dok@ukr.net; Vinnytsia Mykhailo Kotsiubynskyi State Pedagogical University; Ostroz'koho st., 32, Vinnytsia, 21100, Ukraine.

Holovkina V.V.; http://orcid.org/0000-0001-9912-7754; akvavita72@gmail.com; Vinnytsia Mykhailo Kotsiubynskyi State Pedagogical University; Ostroz'koho st., 32, Vinnytsia, 21100, Ukraine.

Salnykova S.V.; http://orcid.org/0000-0003-4675-6105; aqvasveta@ukr.net; Vinnytsia institute of trade and economics of Kyiv national university of trade and economics; Soborna st., 87, Vinnytsia, 21050, Ukraine.

Sulyma A.S.; http://orcid.org/0000-0003-1858-0085; allasulyma16.83@gmail.com; Vinnytsia Mykhailo Kotsiubynskyi State Pedagogical University; Ostroz'koho st., 32, Vinnytsia, 21100, Ukraine.

Brezdeniuk O.Yu. (Corresponding author); http://orcid.org/0000-0003-0844-8777; sandrikk86@gmail.com; Vinnytsia Mykhailo Kotsiubynskyi State Pedagogical University; Ostroz'koho st., 32, Vinnytsia, 21100, Ukraine.

Korolchuk A.P.; http://orcid.org/0000-0003-0372-9246; korolchuk23.76@gmail.com; Vinnytsia Mykhailo Kotsiubynskyi State Pedagogical University; Ostroz'koho st., 32, Vinnytsia, 21100, Ukraine.

Nesterova S.Yu.; http://orcid.org/0000-0002-9621-0218; svetanest01@gmail.com; Vinnytsia Mykhailo Kotsiubynskyi State Pedagogical University; Ostroz'koho st., 32, Vinnytsia, 21100, Ukraine.

Cite this article as: Furman YuM, Holovkina VV, Salnykova SV, Sulyma AS, Brezdeniuk OYu, Korolchuk AP, Nesterova SYu. Effect of swimming with the use of aqua fitness elements and interval hypoxic training on the physical fitness of boys aged 11-12 years. Pedagogics, psychology, medical-biological problems of physical training and sports, 2018;22(4):184-188. doi:10.15561/18189172.2018.0403

The electronic version of this article is the complete one and can be found online at: http://www.sportpedagogy.org.ua/index.php/PPS/issue/archive

This is an Open Access article distributed under the terms of the Creative Commons Attribution License, which permits unrestricted use, distribution, and reproduction in any medium, provided the original work is properly cited (http://creativecommons.org/licenses/by/4.0/deed.en).

Received: 13.01 .2018

Accepted: 16.02.2018; Published: 30.08.2018 